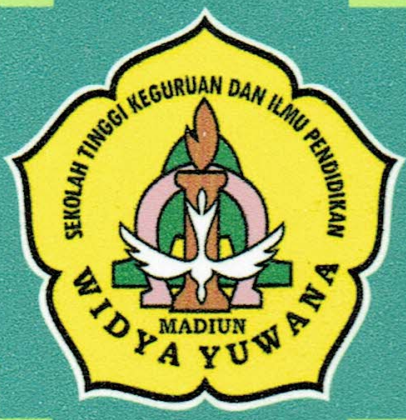

Vol, 7, Tahun ke.4, April 2012

ISSN; 2085-0743

REMAJA: SUMBER DAYA INSANI MENYONGSONG KEMANDIRIAN BANGSA INDONESIA JS. Wibowo Singgih

REMAJA DAN PENGHAYATAN EKARISTI: SUATU HABITUS

BARU

Ola Rongan Wilhelmus

REMAJA KATOLIK, GEREJA, DAN EKARISTI Agustinus Supriyadi

PERAYAAN EKARISTI HARI MINGGU DI PAROKI DAN PERKEMBANGAN HIDUP ROHANI KAUM REMAJA: SEBUAH PELUANG Don Bosco Karnan Ardijanto

STRATEGI MENJADIKAN REMAJA MUSIM SEMI BAGI MASYARAKAT, BANGSA DAN GEREJA Antonius Tse

PROBLEM DAN ABORSI DITINJAU DARI MORAL KATOLIK SERTA USAHA MEMAKNAI LITURGI UNTUK MENGURANGI

PRAKTEK ABORSI DI TENGAH REMAJA KATOLIK Antonius Virdei Eresto Gaudiawan

PROBLEM REMAJA DAN PENILAIAN MORAL KATOLIK TENTANG SEX DI LUAR NIKAH Suparto

DOSA DAN RAHMAT SEKRAMEN PENGAKUAN DOSA BAGI REMAJA Robertus Joko Sulistyo

ANIMASI PERAYAAN TOBAT YANG TEPAT BAGI REMAJA Aloysius Suhardi

REMAJA DAN MASA DEPANNYA: SEBUAH UPAYA PASTORAL BAGI REMAJA Albert I Ketut Deni Wijaya

BELAJAR SEBAGAI AKTIVITAS REMAJA MEMPERSIAPKAN MASA DEPAN Agustinus Wisnu Dewantara

Lembaga Penelitian

Sekolah Tinggi Keguruan dan Ilmu Pendidikan "Widya Yuwana" MADIUN 


\section{JPAK JURNAL PENDIDIKAN AGAMA KATOLIK}

Jurnal Pendidikan Agama Katolik (JPAK) adalah media komunikasi ilmiah yang dimaksudkan untuk mewadahi hasil penelitian, hasil studi, atau kajian ilmiah yang berkaitan dengan Pendidikan Agama Katolik sebagai salah satu bentuk sumbangan STKIP Widya Yuwana Madiun bagi pengembangan Pendidikan Agama Katolik pada umumnya.

\section{Penasihat}

Ketua Yayasan Widya Yuwana Madiun

Pelindung

Ketua STKIP Widya Yuwana Madiun

Penyelenggara

Lembaga Penelitian STKIP Widya Yuwana Madiun

Ketua Penyunting

Hipolitus Kristoforus Kewuel

\section{Penyunting Pelaksana}

FX. Hardi Aswinarno

DB. Karnan Ardijanto

\section{Penyunting Ahli}

John Tondowidjojo

Ola Rongan Wilhelmus

Armada Riyanto

Sekretaris

Gabriel Sunyoto

\section{Alamat Redaksi \\ STKIP Widya Yuwana}

Jln. Mayjend Panjaitan. Tromolpos: 13. Telp. 0351-463208. Fax. 0351-483554

Madiun 63137 - Jawa Timur - Indonesia

Jurnal Pendidikan Agama Katolik (JPAK) diterbitkan oleh Lembaga Penelitian, STKIP Widya Yuwana Madiun. Terbit 2 kali setahun (April dan Oktober). 


\section{JPAK}

Vol. 7, Tahun ke-4, April 2012

ISSN; 2085-0743

\section{DAFTAR ISI}

03 Editorial

05 REMAJA: SUMBER DAYA INSANI MENYONGSONG KEMANDIRIANQBANGSAINDONESIA JS Wibowo Singgih

14 REMAJA DAN PENGHAYATAN EKARISTI: SUATU HABITUS BARU Ola Rongan Wilhelmus

26 REMAJA KATOLIK, GEREJADAN EKARISTI Agustinus Supriyadi

43 PERAYAAN EKARISTI HARI MINGGU DI PAROKI DAN PERKEMBANGAN HIDUP ROHANI KAUM REMAJA: SEBUAH PELUANG

Don Bosco KarnanArdijanto

58 STRATEGI MENJADIKAN REMAJA MUSIM SEMI BAGI MASYARAKAT, BANGSADAN GEREJA Antonius Tse

75 PROBLEM REMAJA DAN ABORSI DITINJAU DARI SEGI MORAL KATOLIK SERTA USAHA MEMAKNAI LITURGI UNTUK MENGURANGI PRAKTEK ABORSI DI TENGAHN REMAJAKATOLIK Antonius Virdei Eresto Gaudiawan

102 PROBLEM REMAJA DAN PENILAIAN MORAL KATOLIK TENTANG SEX DI LUAR NIKAH Suparto

119 DOSA DAN RAHMAT SAKRAMEN PENGAKUAN DOSA BAGI REMAJA Robertus Joko Sulistyo 


\section{ANIMASI PERAYAAN TOBAT YANG TEPAT BAGI}

REMAJA

Aloysius Suhardi

142 REMAJA DAN MASA DEPANNYA: SEBUAH UPAYA PASTORALBAGI REMAJA Albert I Ketut Deni Wijaya

155 BELAJAR SEBAGAI AKTIVITAS REMAJA MEMPERSIAPKAN MASA DEPAN

Agustinus Wisnu Dewantara 


\title{
REMAJA DAN PENGHAYATAN EKARISTI: SUATU HABITUS BARU
}

\author{
Ola Rongan Wilhelmus
}

Sekolah Tinggi Keguruan dan Ilmu Pendidikan Agamạ Katolik (STKIP) Widya Yuwana Madiun

\begin{abstract}
Abstrak
Pembaharuan liturgi akan memberi pengaruh yang bertahan lama kepada remaja dalam mengikuti perayaan Ekaristi jikalau para pemimpin Gereja dan petugas pastoral serta umat beriman itu sendiri secara terus menerus membawa remaja kepada Yesus dan injillya lewat pembinaan iman dan cara hidup komunitas Ekaristi yang berorientasi kepada injil dan berakar dalam Yesus. Pembinaan iman dan cara hidup yang berakar pada Yesus dan berorientasi kepada injil ini dapat melahirkan habitus baru dalam diri remaja yaitu prilaku hidup dimana kehidupan seorang remaja tidak lagi dituntun oleh keinginan atau kemauan sendiri malainkan oleh Yesus dan injil. Hidup seperti ini pada gilirannya akan melahirkan sikap hidup remaja yang penuh kasih dan kebaikan, dan bukannya menjadi pokok persoalan dan kebencian.
\end{abstract}

Key Words : Remaja, Penghayatan Ekaristi, Habitus Baru.

\section{Pendahuluan}

Kehadiran remaja dalam Perayaan Ekaristi hari minggu sering dikeluhkan sangat kurang karena berbagai macam alasan. Kenyataan ini sering membuat para pemimpin Gereja (Uskup, Imam) dan petugas pastoral remaja bertanya: "apa yang harus dilakukan untuk membantu remaja supaya tertarik dan bersemangat menghadiri perayaan Ekaristi pada hari minggu? Jawaban yang sering muncul ialah meningkatkan mutu liturgi dengan membuat pelayanan liturgi seperti koor; kotbah; pelayanan lektor, putra altar, pembawa mazmur, 
dan lain-lain lebih relevan atau cocok dengan alam kehidupan remaja. Dengan pemikiran ini, para uskup, imam dan petugas pastoral lebih memusatkan diri pada usaha peningkatan mutu pelayanan liturgi di Gereja dengan tujuan membuat liturgi lebih menarik sehingga bisa memikat lebih banyak remaja menghadiri Ekaristi.

Upaya membuat perayaan Ekaristi diminati banyak remaja melalui pembaharuan liturgi memang penting mengingat liturgi merupakan jalan yang paling efektif untuk mencapai sebuah perubahan sikap yang Ekaristis dalam diri remaja. Namun pembaharuan liturgi ini tidak akan memberi pengaruh yang bertahan lama kepada remaja dalam mengikuti perayaan Ekaristi kecuali jikalau para pemimpin Gereja dan petugas pastoral serta umat beriman itu sendiri secara terus menerus membawa remaja kepada Yesus dan injilNya lewat pembinaan iman dan cara hidup komunitas Ekaristi yang berorientasi kepada Injil dan berakar dalam Yesus.

Pembinaan iman dan cara hidup yang berakar pada Yesus dan berorientasi kepada injil ini dapat melahirkan habitus baru dalam diri remaja yaitu prilaku hidup dimana kehidupan seorang remaja tidak lagi dituntun oleh keinginan atau kemauan sendiri malainkan oleh Yesus dan injil. Hidup seperti ini pada gilirannya akan melahirkan sikap hidup remaja yang penuh kasih dan kebaikan, dan bukannya menjadi pokok persoalan dan kebencian. Tulisan ini secara berturutturut akan membicarakan konsep Pierre Bordieau tentang habitus dan kemudian refleksi tentang perayaan Ekaristi dan habitus baru.

\section{Pierre Bordieau Tentang Habitus Baru}

Konsep tentang "habitus" telah direnungkan secara mendalam oleh Pierre Bourdieu, seorang sosiolog Perancis. Melalui konsep tentang habitus ini, Bordieau mencoba menyelesaikan ketegangan yang terjadi dalam Marxisme ortodoks yaitu: ketegangan antara ekonomi dan kebudayaan. Dalam pandangan Bourdieau, ilmu ékonomi sejauh ini membatasi dirinya cuma pada persoalan produksi serta pertukaran barang dan jasa. Sementara itu kebudayaan hanya berurusan dengan persoalan tata nilai kehidupan (Bourdieau,1992; Kleden, 2005).

Bagi Bourdieau, pandangan yang memisahkan ekonomi dan kebudayaan ini perlu diubah secara total mengingat produksi dan pertukaran terjadi bukan hanya menyangkut barang dan jasa tetapi juga menyangkut bidang kebudayaan dan sosial. Bagi Bordieau, 
seseorang hanya bisa mengalami kemajuan dan keuntungan dalam bidang ekonomi, sosial, dan kebudayaan apabila ia berhasil menghayati atau meragakan suatu habitus tertentu secara spontan. Jadi habitus merupakan modal (capital) untuk keberhasilan dan kemajuan dalam hidup dan kerja seseorang (Bourdieau, 1992).

Dalam diskusi dan refleksi tentang modal atau kapital, Bodieau mengatakan bahwa modal tidak hanya berkaitan dengan kegiatan ekonomi tetapi juga menyangkut kegiatan sosial dan budaya. Karena itu Bordieau kemudian menganalis dan membedakan beberapa jenis modal yaitu: modal ekonomi, kultural, sosial dan simbolik. Modal ekonomi berkaitan dengan segala jenis barang dan jasa yang dengan mudah dapat dikonversi menjadi uang. Modal kultural berhubungan dengan kemampuan seseorang menguasai informasi dalam segala bentuk. Modal sosial lebih menyangkut keterampilan seseorang menggunakan semua sumberdaya network yang dipakai untuk membangun suatu relasi sosial atau keanggotaan dengan orang lain atau kelompok orang tertentu. Kemudian modal simbolik merupakan status (sosial atau ekonomi) yang diberikan kepada seseorang setelah orang itu mendapat pengakuan atau penghargaan karena jasa atau keberhasilan tertentu yang ia capai (Bourdieau, 1984; Kleden, 2005).

Dalam suatu masyarakat yang sangat menghargai uang, seseorang yang memiliki modal uang akan mendapatkan keuntungan simbolik (symbolic profit) yang tinggi dalam bidang ekonomi. Sebaliknya seorang aktivis yang memiliki modal sosial seperti jaringan sosial dan komunikasi (networking) yang luas akan mendapatkan banyak keuntungan simbolik dalam kehidupan sosial. Demikian pula dalam bidang pendidikan dan kebudayaan, seorang akademisi atau intelektual yang memiliki pengetahuan yang luas serta menguasai informasi secara baik akan mendapatkan banyak keuntungan simbolik dalam dunia kebudayaan (Bourdieau,1984).

Melalui analisisnya tentang berbagai bentuk kapital itu, Bordieau menunjukkan bahwa segala kategori yang ada dalam dunia pasar barang atau jasa (economic market) berlaku pula dalam bidang sosial dan kebudayaan. Jadi ada pasar ekonomi (economic market), ada pasar budaya (cultural market) dan ada juga pasar sosial (social market) yang dinamikanya tidak banyak berbeda. Produksi dan pertukaran tidak hanya terjadi dan berlaku untuk barang dan jasa tetapi juga untuk bidang sosial dan budaya (Bourdieau, 1992; 1984).

Bordieau mengatakan bahwa pasar (field) dalam kehidupan 
ekonomi, sosial dan budaya memainkan peranan sangat penting karena pasar itu memuat berbagai posisi dan bentuk relasi personal antara agen sosial yang terlibat atau berkecimpung di dalamnya. Sikapdan tanggapan seseorang terhadap posisi dan relasi dalam pasar atau field itusangat bergantung pada habitus yang dimiliki seseorang. Oleh karena itu habitus perlu dibentuk, dilatih dan dibiasakan secara terus-menerus atau berulang kali supaya mampu merespon secara tepat tuntutan prilaku dan relasi yang dibutuhkan dalam pasar ekonomi, sosial dan budaya (Bourdieau, 1992; 1984).

Pierre Bordieau mengatakan bahwa setiap sikap, watak, dan prilaku:seseorang terhadap suatu rangsangan atau tuntutan kerja dan pergaulan tidak terjadi secara instan malainkan berakar dalam sejarah hidup seseorang yang sudah membadan. Oleh karena itu setiap sikap atau reaksi sekecil apapun terhadap orang lain atau rangsangan tertentu sangat dipengaruhi oleh keseluruhan sejarah hidup dan relasi seseorang dengan orang lain dan lingkungan dimana ia dibentuk. Jadi habitus dibangun melalui pengalaman hidup, relasi, dan penyesuaian diri seseorang dengan orang lain dalam lingkungan dan tuntutan hidup tertentu. Dengan kata lain, habitus terbentuk melalui proses belajar yang terjadi secara kreatif dengan tujuan memproduksi pikiran, persepsi, ekspresi, dan tindakan seseorang untuk merespon suatu situasi sosial ataupun historis yang dihadapi (Kleden, 2005; Bordieau 1986).

Bordieau sendiri mengartikan habitus sebagai sebuah perangkat disposisi (watak atau kebiasaan berprilaku) yang bertahan lama dan diperoleh melalui latihan berulang kali. Habitus lahir dari kondisi sosial tertentu di mana habitus itu diproduksi (structured structures): Habitus yang dimiliki seseorang berfungsi sebagai kerangka yang melahirkan dan memberi bentuk kepada persepsi, representasi, dan tindakan seseorang (Kleden, 2005; Bordieau, 1986):

Nota Pastoral Sidang KWI, November 2004 secara lebih sederhana mengartikan habitus sebagai seperangkat "kebiasaan, watak, habit, atau gugus insting individual maupun kolektif. Gugus insting ini membentuk cara merasa, berpikir, melihat, memahami, mendekati, bertindak, dan berelasi dengan seseorang atau sekelompok" orang tertentu.

Kata "gugus" menunjukkan adanya kesatuan dari sejumlah elemen pembentuk dan saling terkait secara erat; saling mendukung, dankonsisten. KWI (2004) mengatakan bahwa elemen-elemen dasar 
itu antara lain "sikap dasar terhadap Tuhan, diri sendiri, keluarga, rekan kerja, manusia, masyarakat, pemerintah, dunia bisnis, perempuan, lingkungan hidup, dan sebagainya. Elemen-elemen itu beroperasi secara spontan melalui keseluruhan prilaku dan tutur kata seseorang ataupun sekelompok orang. Elemen-elemen ini akan menjadi habitus bila mereka saling terkait, mendukung, dan mendasari prilaku atau reaksi seseorang terhadap masalah yang dihadapi baik secara emotif, kognitif, dan psiko-motoris.

Insting yang dimaksudkan dalam kaitannya dengan habitus bukannya insting dalam arti naluri yang sudah tertanam dalam diri seseorang dan tak bisa diubah, tetapi kemampuan bereaksi yang kurang-lebih spontan dari seseorang terhadap suatu rangsangan atau masalah yang dihadapi. Kemampuan memberi reaksi secara spontan ini akan menjelma dalam seluruh sikap dan tindakan seseorang yang oleh Bordieau disebut sebagai "cara merasa, berpikir, melihat, memahami, mendekati, bertindak, dan berelasi dengan seseorang atau sekelompok orang. Habitus dapat diubah dan dibentuk melalui suatu proses yang relatif panjang (KWI, 2004; 2005).

Habitus lahir karena faktor eksogen seperti lingkungan, pengalaman, dan pendidikan yang mempengaruhi prilaku hidup seseorang secara spontan. Jadi habitus bukannya hasil dari sebuah refleksi, kesadaran atau pertimbangan rasional malainkan sesuatu yang spontan. Meskipun demikian, habitus juga bukannya suatu gerakan mekanistis yang tidak memiliki latar belakang sejarah sama sekali. Habitus bukannya a state of mind tetapi a state of body yang dilatarbelakangi oleh the site of incorporated history. Habitus bisa terarah kepada tujuan dan hasil tindakan tertentu tetapi tanpa ada maksud secara sadar untuk mencapai hasil-hasil tersebut (Bourdieau, $1992 ; 1984$ )

Terkadang orang bertanya, apa habitus itu berbeda dengan apa yang disebut pola-pola budaya? Perbedaannya ialah kebudayaan sudah diterima sebagai given sedangkan habitus atau sikap lebih ditentukan oleh latihan yang dilakukan secara berulang kali (inculcation) sampai pada titik dimana sikap itu dapat muncul secara spontan ketika berhadapan dengan rangsangan tertentu. Sikap spontan ini bisa disamakan dengan sikap seseorang yang langsung menghentikan kendaraannya ketika berhadapan dengan lampu lalulintas berwarna merah. Habitus lebih dilihat sebagai kecenderungan bertingkah-laku yang sudah membadan dalam diri seseorang untuk melakukan persepsi dan tindakan tertentu tanpa ada 
kaitan langsung dengan norma-norma yang disadari (Kleden, 2005).

\section{Ekaristi dan Remaja: Suatu Habitus Baru}

Konsep tentang habitus baru yang dikembangkan Bordieau berkaitan erat dengan sikap dasar remaja terhadap Ekaristi. Sikap dasar ini mencakup keterlibatan remaja dalam komunitas Ekaristi serta kualitas pemahaman, pendalaman, dan penghayatan remaja tentang Ekaristi dalam komunitas Ekaristi dan di tengah masyarakat (Bdk. FABC, 2010).

Keterlibatan remaja dalam komunitas Ekaristi serta pemahaman, pendalaman dan penghayatan remaja akan Ekaristis dapat melahirkan habitus injili yaitu kasih, pengampunan, pertobatan, dan pembaharuan hidup. Untuk hal ini remaja perlu memiliki pemahaman yang benar tentang hakekat perayaan Ekaristi dalam suatu komunitas Ekaristi.

\subsection{Ekaristi Merupakan Suatu Kenangan Suci}

Perayaan Ekaristi pada tempat pertama merupakan suatu kenangan suci sebab di dalam komunitas Ekaristi remaja mengenangkan kembali dan melanjutkan perjamuan akhir yang dilakukan Yesus dan para rasulNya. Dalam Ekaristi, remaja mengenangkan dan menghidupkan kembali kasih dan kebaikan Yesus yang diberikan kepada setiap orang melalui hidup, sengsara, kematian, dan kebangkitanNya (Kenan, 2008).

Booth (2006) melihat arti "Kenangan" dalam perayaan Ekaristi sebagai "identitas" komunitas kristen yaitu "komunitas kenangan". Dikatakan sebagai komunitas kenangan sebab dalam Ekaristi para remaja sebagai umat beriman secara bersama-sama mengulangi kata-kata yang Yesus sendiri ucapkan pada malam perjamuan terakhir (bdk. Mrk 14:22-24) sebagaimana tertulis dalam doa syukur agung ke II:

"Demikian pula sesudah perjamuan.........terimalah dan minumlah! Inilah piala darah-Ku, darah perjanjian baru dan kekal, yang ditumpahkan bagimu dan bagi semua orang demi pengampunan dosa. Kenangkan Aku dengan merayakan peristiwa ini".

Perayaan Ekaristi sebagai suatu kenangan suci juga terlihat dari surat St. Paulus kepada umat di Korintus:

"Sebab apa yang telah kuteruskan kepadamu telah aku terima dari Tuhan yaitu bahwa Tuhan Yesus Kristus pada 
waktu malam ia diserahan mengambil roti dan sesudah itu Ia mengucapkan syukur atasnya, Ia memecah-mecahkan roti dan berkata: inilah tubuhKu yang diserahkan bagi kamu, perbuatlah ini sebagai peringatan akan Aku"......(I Kor 11:2326).

Konferensi para uskup Asia-Pasifik (2010) di Manila, Filipina menegaskan bahwa: "kenangan akan Yesus dalam Ekaristi" tidak hanya mengandung arti kenangan akan peristiwa yang dilakukan Yesus pada "perjamuan akhir" dengan para rasulNya, malainkan juga kenangan akan seluruh hidup, wafat dan kebangkitan Yesus. Kenangan akan seluruh karya Allah yang mendamaikan dan menyelamatakan manusia melalui hidup, wafat, dan kebangkitan Yesus.

Ketika mengucapkan kembali kata-kata Yesus dalam perjamuan akhir itu, remaja dalam komunitas Ekaristi merenungkan, menghidupi, dan menghayati kembali karya keselamatan Allah dalam diri Yesus yang tidak hanya terjadi pada masa lampau tetapi juga pada masa sekarang dan akan datang. Identitas komunitas Ekaristi yang terus mengenangkan dan menghayati kasih Allah ini perlu diceriterakan atau diwartakan para remaja kepada komunitas atau orang lain melalui prilaku atau kesaksian hidup konkrit yang berakar dalam Yesus dan berorientasi kepada injil di tengah keluarga, Gereja, dan masyarakat. Ceritera ini dilakukan dengan maksud supaya komunitas lain dapat mengerti siapakah komunitas kristen yang disemangati oleh Ekaristi itu dan apa yang membuat komunitas ini berbeda dari komunitas atau orang lain. Ceritera hidup seperti ini mencerminkan lahirnya suatu habitus baru dimana hidup seorang remaja tidak lagi dituntun oleh keinginan dan kemauan sendiri melainkan oleh keinginan dan kemauan Yesus dan injilNya (Kenan, 2008; Yap Ful Lan, 2010).

\subsection{Ekaristi Sebagai Perjaumuan Suci}

Ekaristi pada periode awal kehidupan komunitas kristen dimengerti sebagai bagian dari perjamuan makan malam yang dirayakan dalam konteks perjamuan atau makan bersama sebuah keluarga atau rumah tangga. Dalam perjamuan Ekaristi ini, umat perdana dan pemimpin komunnitas perdana merenungkan bersama hubungan atau kaitan antara perjamuan Ekaristi yang mereka lakukan ketika itu dengan peristiwa dimana Yesus makan bersama dengan para murid, pemungut cukai, Maria Magdalena, Martha, dan 
dengan orang lain. Melalui peristiwa makan bersama ini, Yesus justeru menyalurkan santapan atau berkat rohani yang membawa pertobatan, perubahan, orientasi baru atau habitus baru dalam diri mereka yang makan bersama dengan Yesus (Kenan, 2008; Yap Ful Lan, 2010).

Dalam konteks Ekaristi sebagai suatu perjamuan suci ini, Yoseph Fitzmyer (1990) dalam The New Jerome Biblical Commentary mengatakan bahwa Ekaristi merupakan perjamuan suci dimana remaja dan umat beriman lainnya sebagai anggota dari komunitas Yesus menerima santapan rohani dari Yesus. Santapan rohani ini memiliki daya yang mampu menumbuhkan keberanian dan kekuatan dalam diri remaja untuk mempertegas keanggotaanya dalam komunitas Ekaristi sebagai komunitas yang beriman dan berorientasi kepada Yesus dan Injilnya. Dalam komuntas Ekaristi ini Yesus hadir untuk membangun komunikasi dan relasi personal dengan para remaja dan sekaligus menyalurkan berkat, kasih, kebaikan, pertobatan, dan pengampunan kepada para remaja. Perjamuan Ekaristi dan berkat yang diperoleh dalam perjamuan suci ini akan mencapai kepenuhannya dalam perjamuan ekskatologis atau paripurna.

Paus Benedictus ke XVI (2010) mengatakan bahwa pada saat ini banyak remaja memiliki kerinduan yang sangat mendalam untuk membangun relasi personal dengan orang lain atas dasar kebenaran, kejujuran, cinta, dan solidaritas. Kebanyakan mereka bermimpi membangun suatu persahabatan yang jujur, ingin mengalami cinta yang ikhlas; mendapatkan kenyamanan serta kepastian hidup. Para remaja juga memiliki kecendrungan mencari sesuatu yang indah, unik, dan bernilai dari luar dirinya sendiri. Merespon kerinduan remaja ini, para pemimpin Gereja dan umat beriman perlu membangun suatu komunitas Ekaristi dimana para remaja dapat mengalami komunitas ini sebagai rumah sendiri dan tempat di mana mereka dapat mengalami cinta, kebenaran, solidaritas, serta merasa diterima dan didengarkan. Pengalaman hidup ini dapat melahirkan habitus baru dalam diri remaja yaitu sikap hidup penuh kasih dan kebaikan, dan bukannya sikap hidup yang membawa kebencian, amarah, putus asa, dan kebinasaan.

\subsection{Ekaristi Sebagai Suatu Perayaan Komunal}

Ekaristi merupakan suatu perayaan komunal dan bukannya perayaan perorangan. Dalam perayaan komunal ini, Yesus hadir 
untuk mempersatukan dirinya dengan komunitas ini dan sekaligus menjadi dasar kehidupan komunitas Ekaristi. Dengan demikian, Ekaristi yang dirayakan oleh komunitas Yesus ini hanya memiliki satu dasar yaitu Yesus sendiri (Kenan, 2008; Yap Ful Lan, 2010).

Karena Yesus sebagai dasar kehidupan komunitas Ekaristi ini maka melalui Ekaristi sebagai perayaan komunal, para remaja sebagai umat beriman berkumpul bersama-sama untuk mengungkapkan dirinya sebagai komunitas iman yang percaya kepada Yesus. Iman akan Yesus dalam komunitas ini merupakan realitas penting dan menjadi dasar bagi perayaan Ekaristi. Suatu perayaan Ekaristi hanya bisa disebut sebagai perayaan komunal apabila perayaan ini dirayakan oleh suatu komunitas iman yang percaya dan berorientasi kepada Yesus dan injil (Kenan, 2008; Yap Ful Lan, 2010).

St. Paulus dalam suratnya kepada umat di Korintus mengatakan bahwa sebuah komunitas iman yang ideal mengandaikan beberapa persyaratan penting yaitu: komunitas itu harus satu, beriman pada Yesus Kristus, dan hidup atau berakar dalam Yesus Kristus. Suatu komunitas kristen bisa terdiri dari umat yang berbeda-beda tetapi tetap satu dalam iman akan Yesus dan berorientasi pada injil. Murphy O'Connor mengatakan bahwa kesatuan komuntas iman yang ditunjukkan dalam perayaan Ekaristi bersifat organik. Artinya kesatuan itu bukannya sesuatu yang dibentuk oleh manusia tetapi dibentuk oleh Yesus Kristus sendiri dengan maksud membuat umat beriman terutama para remaja menjadi ciptaan baru (2Kor 5:17). Artinya menjadi remaja yang diperbaharui dan diselamatkan oleh Allah karena percaya kepada Yesus dan berorientasi kepada injil (Bdk. Kenan, 2008; Fitzmyer,1990).

Dalam komunitas yang dibentuk oleh Yesus ini, remaja dapat mengalami komunitas Ekaristi sebagai rumah sendiri dan tempat dimana para remaja dapat berjumpa dan tinggal tinggal bersama Yesus. Tempat dimana para remaja dapat menceriterakan kepada Yesus berbagai pengalaman hidup tentang cinta, kebenaran, solidaritas, kegembiraan, ketenangan, harapan, kerinduan, bakat, minat, dan prestasi, ataupun ketegangan, konflik, penolakan, diskriminasi, kelaparan, ketidakadilan, kekerasan, dan lain-lain yang mereka lihat atau alami sendiri. Di dalam komunitas Ekaristi ini, remaja dapat mengalami perubahan, perkembangan, dan pembaharuan hidup sebagai individu-individu yang beriman pada 
Yesus dan memiliki keberanian untuk memberi kesaksian tentang Yesus di keluarga, Gereja dan masyarakat (Bdk. Paus Benedictus ke XVI, 2010).

Bagi Paulus, komunitas Ekaristi merupakan perpanjangan inkarnasi misi keselamatan Kristus. Apa yang Yesus lakukan selama hidupnya melalui kehadiran fisiknya diteruskan oleh komunitas itu. Karena itu suatu komunitas harus memiliki kesamaan pemahaman tentang Yesus. Jikalau komunitas tidak mempunyai kesamaan pemahaman tentang Yesus, maka komunitas itu tidak akan menjadi sebuah komunitas Kristiani yang satu, beriman, dan berakar dalam Yesus. Di sini umat beriman perlu bertanya kepada dirinya sendiri: seberapa kuat umat dalam suatu keuskupan, paroki, lingkungan atau stasi berorientasi kepada Kristus? Sejauh mana komunitas kristen dalam suatu keuskupan, paroki, stasi, dan lingkungan berupaya membantu remaja untuk mengenal, beriman, dan hidup dalam persatuan dengan Yesus Yesus? (Bdk. Kenan, 2008; Fitzmyer,1990).

Tugas komunitas Ekaristi ialah mendekatkan remaja kepada Yesus serta mendampingi dan menguatkan imannya. Remaja dituntun supaya bertumbuh di dalam iman komunitas Ekaristi dan berani menolak siapa saja yang mengatakan bahwa remaja tidak memerlukan bantuan orangtua, umat beriman, dan komunitas iman dalam membangun iman dan menata hidupnya. Remaja didorong untuk mencari dukungan iman serta model kehidupan yang benar dan jujur dari keluarga, Gereja, dan siapa saja yang beriman kepada Yesus dan mencintai mereka secara iklas (Paus Benedict XVI. 2010).

Banyak pemikiran, informasi, budaya, dan praktek hidup seperti pergaulan bebas, hedonisme, materialisme, konsumerisme, dan budaya instan yang ditayangkan melalui berbagai media masa dan elektronik saat ini telah menyesatkan dan menghancurkan hidup banyak remaja. Budaya dan praktek hidup ini juga mengakibatkan Yesus semakin jauh dan tersingkir dari keseharian hidup remaja. Situasi ini memberi kemungkinan kepada remaja untuk menciptakan sendiri suatu Firdaus tanpa Allah. Akan tetapi sejarah dan pengalaman hidup telah menunjukkan bahwa Firdaus tanpa Allah merupakan neraka atau tempat dimana hidup seorang remaja hanya akan terisi dengan napsu ingat diri, percecokan, perkelahian, dan permusuhan yang menghancurkan remaja dan masa depannya (Paus Benedictus XVI, 2010).

Menghadapi tantangan budaya hidup yang menyesatkan ini, remaja perlu dibimbing oleh dan melalui komunitas Ekaristi untuk 
mengenal dan mengimani Yesus, menyembah serta mendengarkan suaraNya. Rasul Paulus dalam suratnya kepada umat di Kolose (2: 615) berusaha menguatkan iman umat di Kolose yang tertekan oleh pemikiran dan budaya hidup yang menyesatkan, dan sekaligus menekankan kembali makna misteri kematian dan kebangkitan Yesus sebagai dasar kehidupan komunitas Ekaristi.

\section{Penutup}

Komunitas Ekaristi adalah komunitas yang bersatu, utuh, beriman pada Kristus, berakar dalam Kristus dan berorientasi kepada injil. Komunitas ini dibentuk oleh Yesus sendiri dan karena itu Yesus menjadi dasar dari komunitas Ekaristi. Dalam komunitas Ekaristi ini pula Yesus hadir untuk berbagi pengalaman tentang cinta, kegembiraan, ketenangan, penolakan, diskriminasi, kelaparan, ketidakadilan, kekerasan, dan lain-lain yang dilihat atau alami remaja.

Komunitas Ekaristi yang dibangun oleh Yesus ini memiliki daya yang mampu membuat setiap remaja mengalami perubahan, perkembangan, dan pembaharuan hidup secara sehat sebagai individu yang beriman pada Yesus dan memiliki keberanian untuk memberi kesaksian tentang Yesus di tengah keluarga, Gereja, dan masyarakat. Tugas komunitas Ekaristi ialah berupaya mendekatkan para remaja kepada Yesus serta mendampingi dan menguatkan imannya agar remaja terus berkembang dan bertumbuh dalam iman komunitas Ekaristi. 


\section{Daftar Pustaka}

Booth J. William., 2006. Communities of Memory: On Witness, Identity, and Justice. New York: Cornell University Press.

Bourdieu, P., 1980. The Logic of Practice. Stanford, Stanford

University Press.

1984. Distinction: A Social Critique of the Judgement of Taste. London, Routledge.

1986. 'The Forms of Capital'. Handbook of Theory and Research for the Sociology of Capital. J. G. Richardson. New York, Greenwood Press

1992. "The Purpose of Reflexive Sociology," in An Invitation to Reflexive Sociology. Chicago, USA.

FABC., 2010. Living the Eucharist in Asia, The 9th FABC Plenary Assembly, Final Document, Introduction. http://www.fabc. org/

Fitzmyer, J., 1990. "Pauline Theology”. Dalam The New Jerome Biblical Comentary. Pretice Hall

Kenan B. Osborne., 2008. Komunitas, Ekaristi dan Spiritualitas. Kanisius, Jogyakarta.

Kleden, Ignas., 2005. Pierre Bourdieau Dan Konsep Habitus Baru. Kumpulan Makalah dan Bacaan Pelengkap SAGKI

Paus Benedictus XVI., 2010. We Want to Be Able to See Jesus. Papal Message for World Ya outh Day. 2010. Zenit.org. 3 September

Yap Ful Lan., 2010. Living the Eucharist in Asia. East Asian Pastoral Review. Vol.47. No. 4 